\title{
Pengujian Black Box pada Aplikasi Sistem Kasir Berbasis Website Menggunakan Teknik Equivalence Partitions
}

\author{
Irfan Abdul Aziz ${ }^{1}$, Bagas Setiawan ${ }^{2}$, Rashad Khanh $^{3}$, Guruh Nurdiyansyah ${ }^{4}$, Yulianti Yulianti ${ }^{5}$ \\ Teknik Informatika, Universitas Pamulang, Tangerang Selatan, Banten, Indonesia \\ E-mail: 'irfanabdul_aziz@yahoo.com, ${ }^{2}$ bagasstwn19@gmail.com, ${ }^{3}$ rashadkhanh74@gmail.com, \\ ${ }^{4}$ guruh.nurdiyansyah18@gmail.com, yulianti@unpam.ac.id
}

Submitted Date: March 21 $1^{\text {st }}, 2020$

Revised Date: April 06 $6^{\text {th }}, 2020$
Reviewed Date: April $05^{\text {th }}, 2020$
Accepted Date: April $29^{\text {th }}, 2020$

\begin{abstract}
Nowadays, computers have an important role in human life. Because computers really help humans in carrying out tasks through the applications and features available according to human needs. Most of the people who have a business doing all their activities are more computerized on a regular basis for reasons of time, less risk and faster decisions than without a computer. For this reason, the purpose of this study is to produce a cashier information system that can conduct deposit sales and produce multiple transaction reports. This Cashier System was designed using php and MySQL programming languages with XAMPP software.
\end{abstract}

Keyword: Cashier Information System; Software Testing; Black Box; Equivalence Partitions

\section{Abstrak}

Saat ini, komputer sangat memiliki peranan penting di dalam kehidupan manusia. Karena komputer sangat membantu manusia dalam manjalankan tugas melalui aplikai dan fitur yang tersedia sesuai kebutuhan manusia. Sebagian besar mansuai yang mempunyai usaha melakukan semua aktivitas mereka lebih terkomputerisasi dengan teratur karena alasan waktu, lebih sedikit resiko dan keputusan yang lebih cepat dibandingkan tanpa komputer. Dengan alasan tersebut, maka tujuan penelitian ini adalah menghasilkan sebuah sistem informasi kasir yang bisa melakukan penjualan penyetokan dan menghasilkan beberapa laporan transaksi. Sistem Kasir ini dirancang dengan menggunakan Bahasa pemograman PHP dan MySQL dengan perangkat lunak XAMPP.

Kata Kunci: Sistem Informasi Kasr; Pengujian Software, Black Box, Equivalence Partitions

\section{Pendahuluan}

Pengujian merupakan bagian dari aktifitas pengembangan sistem yang sudah direncanakan dan sangat sistematis untuk menguji ataupun mengevaluasi kebeneran yang diinginkan dari kualitas perangkat lunak. Bahwa pengujian perangkat lunak adalah pekerjaan yang sulit. Beberapa orang mengatakan bahwa jika hanya sekedar menguji perangkat lunak saja, semua manusia juga bisa dan tidak perlu susah-susah menjadi programmer. Tapi pengujian perangkat lunak adalah hal yang disiplin tersendiri dan merupakan bagian dari proses pengembangan perangakt lunak. Hampir semua metode dari perangkat lunak menempatkan pengujian perangkat lunak sebagai bagian utama dari sebuah proses perkembangan. Kegagalan saat pengujian perangkat lunak dapat menyebabkan produk yang dihasilkan tidak berjalan dengan baik dan dapat menimbulkan suatu kerugian yang besar, dan bagian dari kerugian ini bisa terhindar jika melakukan pengujian pada perangkat lunak. Tujuan utama dari pengujian perangakat lunak yaitu untuk memastikan bahwa perangkat lunak yang dihasilkan sesuai dengan kebutuhan yang sebelumnya ditentukan. Ketika kebutuhan dari suatu sistem yang telah disusun maka seharusnya sudah ada suatu pengujian perencanaan.

Selain itu, proses testing membutuhkan tujuan akhir yang dinilai sehingga seorang penguji bisa berhenti melakukan suatu pengujian ketika tujuan-tujuannya sudah tercapai. Pengujian pada 
perangkat lunak biasanya diartikan pengujian yang dilakukan secara otomatis. Maksudnya, dilakukan menggunakan perangkat lunak lain untuk merekam kegiatan-kegiatan pengguna dan mesimulasikan penggunaan komponen internal.

Adapun perangkat lunak yang akan diuji adalah Fitur Laporan Penjualan, fitur ini merupakan hak yang wajib ada dalam program kasir atau POS. Dengan adanya fitur laporan penjualan, Anda akan mengetahui perkembangan bisnis Anda secara waktu yang sebenarnya dan mudah (Purnama, 2013). Software kasir mampu menyediakan laporan penjualan secara lengkap dan cepat, bahkan Anda juga bisa mengetahui laporan penjualan dari perusahaan cabang yang tersebar di berbagai lokasi (Suprayitno \& Wardati, 2012).

Dari fitur ini, Anda bisa menentukan jenis produk yang akan dikembangkan selanjutnya untuk menarik minat konsumen. Dalam program kasir tersebut, Anda bisa mengatur bentuk laporan yang Anda butuhkan secara berjangka. Fitur pilihan metode pembayaran pada zaman sekarang, konsumen selalu menginginkan metode pembayaran yang cepat dan mudah (Astarina \& Riasti, 2013). Bahkan kebanyakan dari mereka melakukan pembayaran secara non-tunai, seperti menggunakan kartu debit atau kredit. Karena itulah Anda sebagai pebisnis harus menggunakan aplikasi POS dengan fitur pilihan metode pembayaran. Pilihan metode pembayaran konsumen tidak hanya secara tunai saja, tetapi lengkapi juga dengan non tunai. Software kasir Anda akan terintegrasi dengan bank terkait atau yang bekerja sama dengan perusahaan Anda. Sehingga konsumen pun lebih nyaman dalam bertransaksi di toko Anda. Dan ada beberapa obyek seperti data kasir, kategori produk, data produk, data orderan, data supplier.

Ketika software yang dikembangkan telah selesai, pelanggan akan memeriksa apakah sudah sesuai dengan harapan. Kepuasan pelanggan tergantung pada kualitas perangkat lunak dan kualitas sejumlah perangkat lunak perlu dijaga dengan beberapa alasan (Cholifah, Yulianingsih, $\&$ Sagita, 2018). Pengujian yang dilakukan harus dirancang dengan baik agar dapat menemukan kesalahan secara sistematis dan dapat diperbaiki dalam waktu yang singkat. (Kurniawan, Maulana, Sukma, Keumala, \& Saifudin, 2020)

\section{Metodologi}

Sistem informasi kasir yang dikembangkan ditujukan untuk melakukan transaksi penjualan, penyetokan dan menghasilkan beberapa laporan transaksi. Sistem informasi adalah kumpulan dari sub-sub sistem yang saling terintegrasi dan berkolaborasi untuk menyelesaikan masalah tertentu dengan cara mengolah data sehingga memiliki nilai tambah dan bermanfaat bagi pengguna (Taufiq, 2018).

Pengujian software merupakan tahapan pengembangan yang sangat penting untuk memastikan perangkat lunak yang sudah atau sedang dikembangkan dapat berjalan sesuai dengan kebutuhan yang telah ditetapkan. Pengujian merupakan suatu proses pelaksanaan program yang bertujuan menemukan kesalahan dan memperbaikinya sehingga sistem dikatakan layak untuk digunakan (Nurudin, Jayanti, Saputro, Saputra, \& Yulianti, 2019). Pengujian perangkat lunak untuk melakukan verifikasi dan validasi bahwa software yang telah dibuat seuai dengan keinginan dari perusahaan. Pengujian merupakan bagian dari tahapan yang tidak dapat dipisahkan dari siklus hidup pemgembangan perangkat lunak seperti analisis, desain, dan pengkodean. (Shi, 2010) Pengujian perangakt lunak sangat penting karena memiliki implikasi terhadap kualitas software (Myres, Badgett, \& Sandler, 2012). Pengujian tidak dapat dihindari karena pada aktivitas produksi memiliki peluang terjadinya kesalahan yang dibuat pengguna sangat besar dan ketidakmampuam pengguna untuk melakukan komunikais dengan sempurna. Sehingga perkembangan perangakat lunak harus diiringi aktivitas jaminan kualitas. (Liana, 2015)

Metode Black box Testing merupakan sebuah metode yang dipakai untuk menguji sebuah software tanpa harus memperhatikan detail software. Pada pengujian black box dilakukan hanya mengambil hasil eksekusi melalui data uji dan memeriksa fungsional dari perangkat lunak (Krismadi, et al., 2019). Pada pengujian black box, estimasi banyaknya data uji dapat dihitung melalui banyaknya field data masukan yang akan diuji, aturan masukan yang harus dipenuhi serta batas masukan, baik batas atas maupun batas bawah yang memenuhi spesifikasi. Tidak ada upaya untuk mengetahui kode program apa yang output pakai.

Equivalence Partitioning merupakan sebuah pengujian berdasarkan masukkan data pada setiap form, metode pengujian yang memecah domain masukan dari program ke dalam kelas-kelas data sehingga Test Case dapat diperoleh. Perancangan 
Test Case Equivalence untuk kondisi masukan yang menggambarkan kumpulan keadaan yang valid atau tidak. Equivalence Partitioning berdasarkan pada premis masukan dan keluaran dari suatu komponen yang dipartisi ke dalam kelaskelas, menurut spesifikasi dari komponen tersebut, yang akan diperlakukan sama (ekivalen) oleh komponen tersebut (Asnawati, 2015).

Pada proses pengujian terdapat tabel Test Case yang berfungsi untuk menyimpulkan apakah system berhasil dalam pengujian tipe tersebuat atau tidak. Berikut terdapat penjelasan dari tabel Test Case.

\section{SISTEM KASIR}

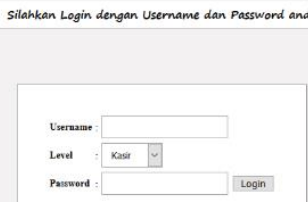

Gambar 1 Rancangan Antarmuka Halaman Login

Dari form pada Gambar 1 ada beberapa rencana pengujian. Form Username dan Password diisi dengan huruf dan angka dengan tepat dan tidak boleh kosong, jika Username dan Password diisi dengan data yang salah atau kosong, maka akan muncul peringatan. Pada bagian Level, dipilih dengan tepat sesuai Username dan Password yang isi, jika Username dan Password sudah di isi dengan benar namun Level tidak dipilih dengan benar, maka akan muncul pesan peringatan.

Mengubah user data kasir oleh admin

\section{SISTEM KASIR}

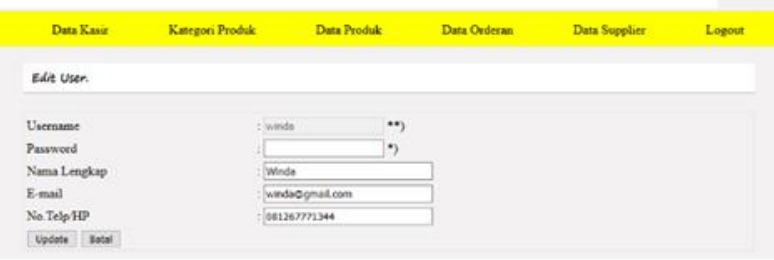

Gambar 2 Form edit user data kasir

Dari form pada Gambar 2 ada beberapa rencana pengujian. Form Password dan E-mail dapat diisi dengan huruf, angka dan symbol, dan khusus form Password diisi dengan password lama atau baru, form Nama Lengkap harus diisi dengan huruf, form No.Telp/HP harus diisi dengan angka, apabila tidak diisi dengan benar atau kosong, maka data tidak dapat tersimpan dan tidak berubah.

Tabel 1 Rancangan Test Case Halaman Login

\begin{tabular}{|l|l|l|}
\hline ID & \multicolumn{1}{|c|}{ Deskripsi Pengujian } & \multicolumn{1}{c|}{ Hasil yang Diharapkan } \\
\hline A1 & $\begin{array}{l}\text { Pada saat login, masukan username, level, dan } \\
\text { password dengan tepat }\end{array}$ & $\begin{array}{l}\text { Tampilan halaman utama sesuai dengan } \\
\text { data yang sudah dimasukkan }\end{array}$ \\
\hline A2 & $\begin{array}{l}\text { Pada saat login dan memilih level admin, masukan } \\
\text { username dan password yang belum terdaftar atau } \\
\text { salah atau tidak mengisi username/password }\end{array}$ & $\begin{array}{l}\text { Tampilan pesan peringatan Username } \\
\text { atau Password anda salah }\end{array}$ \\
\hline A3 & $\begin{array}{l}\text { Pada saat login dan memilih level kasir, masukan } \\
\text { username dan password yang belum terdaftar atau } \\
\text { salah atau tidak mengisi username/password }\end{array}$ & $\begin{array}{l}\text { Tampilan pesan peringatan Username } \\
\text { dan Password anda salah atau account } \\
\text { anda belum di aktifkan. }\end{array}$ \\
\hline
\end{tabular}

Tabel 2 Rancangan test case edit data kasir

\begin{tabular}{|l|l|l|}
\hline ID & \multicolumn{1}{|c|}{ Deskripsi Pengujian } & \multicolumn{2}{c|}{ Hasil yang Diharapkan } \\
\hline B1 & $\begin{array}{l}\text { Mengisi Nama Lengkap dengan "Winda", No.Telp/Hp } \\
\text { diisi dengan "081267771344", Password diisi dengan } \\
\text { "1234abc", Email diisi dengan "winda@gmail.com" }\end{array}$ & $\begin{array}{l}\text { Sistem mampu menyimpan data } \\
\text { kedalam database dan mengalami } \\
\text { perubahan tampilan pada halaman } \\
\text { utama }\end{array}$ \\
\hline
\end{tabular}


B2 Mengisi Nama Lengkap dengan "Winda12", No.Telp/Hp diisi dengan "081267771344aa", Password diisi dengan "1234abc" atau tidak diisi, Email diisi dengan Sistem menolak untuk menyimpan "winda@gmail.com" atau tidak diisi data dan data padad halaman utama tidak berubah

Mengubah dan menambahkan kategori produk oleh admin

\section{SISTEM KASIR}

\section{SISTEM KASIR}

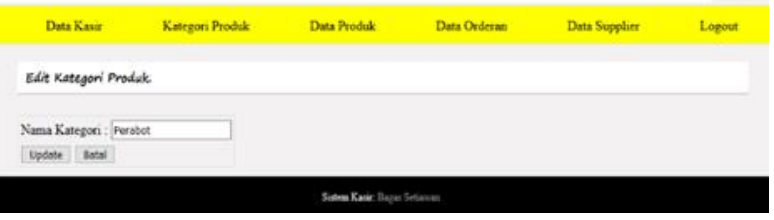

Gambar 3 Mengubah data kategori produk

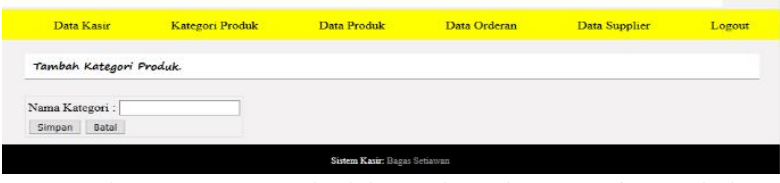

Gambar 4 Menambahkan data kategori produk

Dari form di Gambar 3 dan Gambar 4 ada beberapa rencana pengujian. Form Nama Kategori diisi dengan huruf dan angka tidak boleh kosong, jika form tidak diisi maka data tidak akan tersimpan.

Tabel 3 Rancangan Test Case Edit dan Update Kategori Produk

\begin{tabular}{|c|l|l|}
\hline ID & \multicolumn{1}{|c|}{ Deskripsi Pengujian } & \multicolumn{1}{c|}{ Hasil yang Diharapkan } \\
\hline C1 & $\begin{array}{l}\text { Mengisi Nama Kategori dengan } \\
\text { "Parabot" }\end{array}$ & $\begin{array}{l}\text { Sistem mampu menyimpan data kedalam database dan } \\
\text { mengalami perubahan tampilan pada halaman utama }\end{array}$ \\
\hline C2 & Tidak mengisi Nama Kategori & $\begin{array}{l}\text { Sistem menolak untuk menyimpan data dan data padad } \\
\text { halaman utama tidak berubah }\end{array}$ \\
\hline
\end{tabular}
$\operatorname{admin}$

Mengubah dan menambah data produk oleh

\section{SISTEM KASIR}

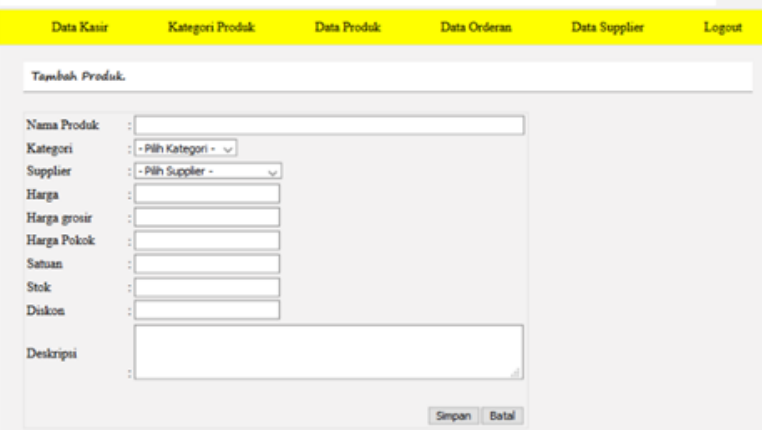

Gambar 5 Menambah data produk oleh Admin

\section{SISTEM KASIR}

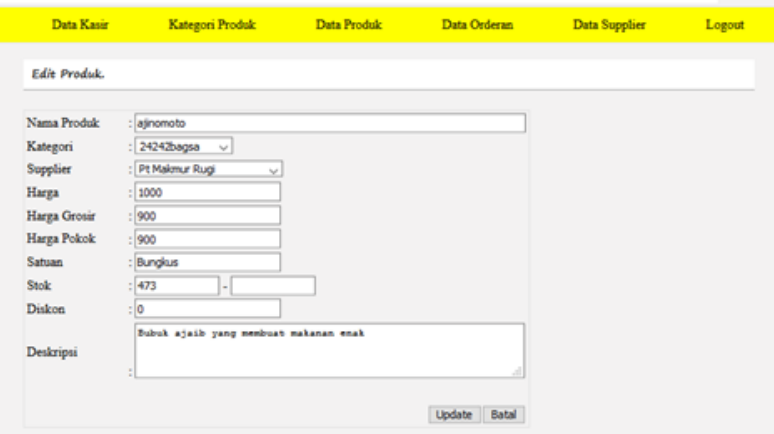

Gambar 6 Mengubah data produk oleh Admin

Dari form pada Gambar 5 dan Gambar 6 ada beberapa rencana pengujian. Form Nama Produk harus diisi dengan huruf, angka dan simbol, form Harga, Harga Grosir, Harga Pokok,Stock dan Diskon harus diisi dengan angka, form Satuan dan Deskripsi dapat diisi dengan angka dan huruf atau dikosongkan, apabila tidak diisi dengan benar pada salah satu form, maka data tidak dapat tersimpan dan tidak berubah.

Tabel 4 Rancangan test case mengubah dan menambah data produk 


\begin{tabular}{|l|l|l|}
\hline ID & \multicolumn{1}{|c|}{ Deskripsi Pengujian } & \multicolumn{1}{|c|}{ Hasil yang Diharapkan } \\
\hline D1 & $\begin{array}{l}\text { Mengisi Nama Produk dengan "ajinomoto", Harga diisi dengan } \\
\text { "1000", Harga Groris diisi dengan "900", Harga Pokok diisi } \\
\text { dengan "900", Satuan diisi dengan "Bungkus" atau kosong, } \\
\text { Stock diisi dengan "497", Diskon diisi dengan "0", Deskripsi } \\
\text { diisi dengan "Mantap" atau kosong }\end{array}$ & $\begin{array}{l}\text { Sistem mampu menyimpan } \\
\text { data kedalam database dan } \\
\text { mengalami perubahan tampilan } \\
\text { pada halaman utama }\end{array}$ \\
\hline D2 & $\begin{array}{l}\text { Mengisi Nama Produk dengan "ajinomoto1", Harga diisi } \\
\text { dengan "1000abc", Harga Groris diisi dengan "900ea", Harga }\end{array}$ & $\begin{array}{l}\text { Sistem menolak untuk } \\
\text { menyimpan data dan data } \\
\text { padad halaman utama tidak } \\
\text { atau kosong, Stock diisi dengan "497z", Diskon diisi dengan } \\
\text { berubah } \\
\text { "0w", Deskripsi diisi dengan "Mantap^_^" atau kosong }\end{array}$ \\
\hline
\end{tabular}

Mencari kode barang oleh kasir

\section{SISTEM KASIR}

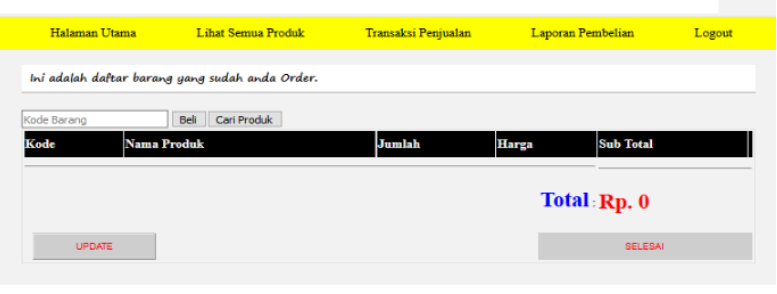

Dari form pada Gambar 8 beberapa rencana pengujian. Form Kode Barang harus diisi dengan angka yang terdaftar pada List Semua Produk, jika form dimasukan dengan kode yang tidak terdaftar atau tidak mengisi kode dan klik tombol Beli, maka akan muncul peringatan.

Gambar 7 Mencari kode barang

Tabel 5 Rancangan test case mencari kode barang

\begin{tabular}{|l|l|l|}
\hline ID & \multicolumn{1}{|c|}{ Deskripsi Pengujian } & \multicolumn{1}{c|}{ Hasil Yang Diharapkan } \\
\hline E1 & $\begin{array}{l}\text { Mengisi Kode Barang dengan kode yang } \\
\text { terdaftar pada Daftar Semua Produk lalu klik } \\
\text { tombol Beli }\end{array}$ & $\begin{array}{l}\text { Sistem mampu mencari data dan menambahkan } \\
\text { barang sesuai kode yang dicari ke tabel Transaksi } \\
\text { Penjualan }\end{array}$ \\
\hline E2 & $\begin{array}{l}\text { Tidak mengisi Kode Barang lalu klik tombol } \\
\text { Beli }\end{array}$ & $\begin{array}{l}\text { Akan muncul peringatan "Anda belum } \\
\text { mengisikan Kode Barang." }\end{array}$ \\
\hline E3 & $\begin{array}{l}\text { Mengisi Kode Barang dengan kode yang tidak } \\
\text { terdaftar pada Daftar Semua Produk lalu klik } \\
\text { tombol Beli }\end{array}$ & $\begin{array}{l}\text { Akan muncul peringatan "Maaf, Stok Produk } \\
\text { Habis atau Produk Tidak Tersedia..." }\end{array}$ \\
\hline
\end{tabular}

Mengubah Jumlah Barang pada Transaksi Penjualan oleh Kasir

\section{SISTEM KASIR}

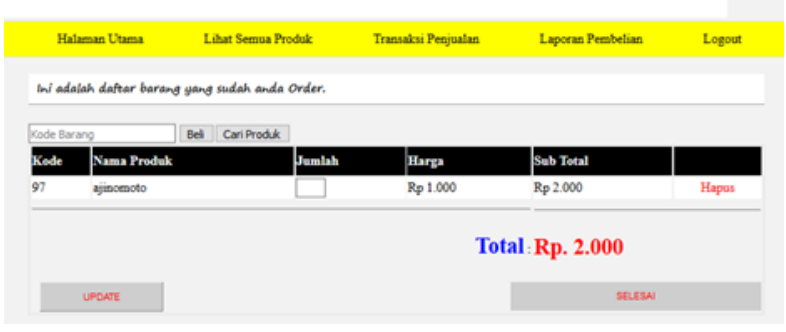

Gambar 8 Mengubah jumlah barang

Dari form pada Gambar 8 beberapa rencana pengujian. Form Jumlah harus diisi dengan angka sesuai dengan jumlah yang tersedia pada daftar Semua Produk dan tidak boleh kosong, jika tidak diisi atau diisi dengan jumlah melebihi stok yang sudah ditetunkan maka jumlah akan kembali ke jumlah sebelumnya. 
Tabel 6 Rancangan test case mengubah jumah barang pada transaksi penjualan

\begin{tabular}{|l|l|l|}
\hline ID & \multicolumn{1}{|c|}{ Deskripsi Pengujian } & \multicolumn{1}{c|}{ Hasil yang Diharapkan } \\
\hline F1 & $\begin{array}{l}\text { Mengisi Jumlah Barang dengan angka } \\
\text { dan stok yang tersedia lalu klik Update }\end{array}$ & $\begin{array}{l}\text { Sistem mampu merubah Jumlah Barang dengan } \\
\text { jumlah yang dinginkan }\end{array}$ \\
\hline F2 & $\begin{array}{l}\text { Tidak mengisi Jumlah Barang dengan } \\
\text { angka }\end{array}$ & $\begin{array}{l}\text { Sistem akan mengembalikan Jumlah Barang ke } \\
\text { jumlah sebelumnya }\end{array}$ \\
\hline F3 & $\begin{array}{l}\text { Mengisi Jumlah Barang dengan angka } \\
\text { namun dengan jumlah yang melebihi stok } \\
\text { yang ada }\end{array}$ & $\begin{array}{l}\text { Sistem akan mengembalikan Jumlah Barang ke } \\
\text { jumlah sebelumnya }\end{array}$ \\
\hline
\end{tabular}

\section{Hasil dan Pembahasan}

Setelah membuatrancangan pengujian, selanjutnya diterapkan dengan melaksanakan pengujian. Pengujian dilaksanakan dengan mengikuti deskripsi pengujian. Hasilnya kemudian dicatat di kolom hasil pengujian. Kesimpulan dibuat berdasarkan penilaian kesesuaian antara hasil pengujian dengan hasil yang diharapkan. Jika hasil pengujiannya sesuai harapan maka disimpulkan sesuai/berhasil. Jika hasil pengujiannya sesuai hasil yang diharapkan maka disimpulkan salah/gagal. Hasil tabel yang telah dilakukan ditunjukan pada Tabel 7.

Tabel 7 Hasil pengujian

\begin{tabular}{|c|c|c|c|c|}
\hline ID & Deskripsi Pengujian & $\begin{array}{c}\text { Hasil yang } \\
\text { Diharapkan }\end{array}$ & Hasil Pengujian & Kesimpulan \\
\hline A1 & $\begin{array}{l}\text { Pada saat login, masukan } \\
\text { username, level, dan password } \\
\text { dengan tepat }\end{array}$ & \begin{tabular}{llr}
\multicolumn{2}{l}{ Tampilan } & halaman \\
utama sesuai & dengan \\
data yang & sudah \\
dimasukkan &
\end{tabular} & $\begin{array}{l}\text { Tampilan halaman } \\
\text { utama sesuai dengan } \\
\text { data yang sudah } \\
\text { dimasukkan }\end{array}$ & Sesuai \\
\hline $\mathrm{A} 2$ & $\begin{array}{l}\text { Pada saat login dan memilih } \\
\text { level admin, masukan } \\
\text { username dan password yang } \\
\text { belum terdaftar atau salah atau } \\
\text { tidak mengisi } \\
\text { username/password }\end{array}$ & $\begin{array}{l}\text { Tampilan pesan } \\
\text { peringatan Username } \\
\text { atau Password anda } \\
\text { salah }\end{array}$ & $\begin{array}{l}\text { Tampilan pesan } \\
\text { peringatan Username } \\
\text { atau Password anda } \\
\text { salah }\end{array}$ & Sesuai \\
\hline A3 & $\begin{array}{l}\text { Pada saat login dan memilih } \\
\text { level kasir, masukan username } \\
\text { dan password yang belum } \\
\text { terdaftar atau salah atau tidak } \\
\text { mengisi username/password }\end{array}$ & $\begin{array}{l}\text { Tampilan pesan } \\
\text { peringatan Username } \\
\text { dan Password anda } \\
\text { salah atau account anda } \\
\text { belum diaktifkan. }\end{array}$ & $\begin{array}{l}\text { Tampilan pesan } \\
\text { peringatan Username } \\
\text { dan Password anda } \\
\text { salah atau account } \\
\text { anda } \\
\text { diaktifkan. }\end{array}$ & Sesuai \\
\hline B1 & $\begin{array}{l}\text { Mengisi Nama Lengkap } \\
\text { dengan "Winda", No.Telp/Hp } \\
\text { diisi dengan "081267771344", } \\
\text { Password diisi dengan } \\
\text { "1234abc", Email diisi dengan } \\
\text { "winda@gmail.com" }\end{array}$ & $\begin{array}{l}\text { Sistem mampu } \\
\text { menyimpan data } \\
\text { kedalam database dan } \\
\text { mengalami perubahan } \\
\text { tampilan pada halaman } \\
\text { utama }\end{array}$ & $\begin{array}{l}\text { Sistem mampu } \\
\text { menyimpan data } \\
\text { kedalam database dan } \\
\text { mengalami } \\
\text { perubahan tampilan } \\
\text { pada halaman utama }\end{array}$ & Sesuai \\
\hline B2 & 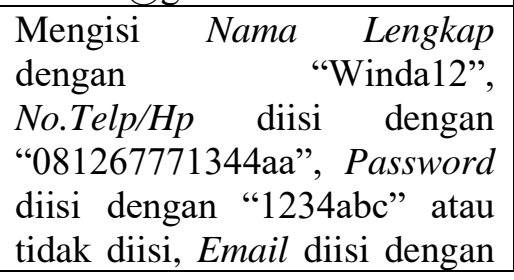 & $\begin{array}{l}\text { Sistem menolak untuk } \\
\text { menyimpan data dan } \\
\text { data padad halaman } \\
\text { utama tidak berubah }\end{array}$ & $\begin{array}{l}\text { Sistem menolak } \\
\text { untuk menyimpan } \\
\text { data dan data padad } \\
\text { halaman utama tidak } \\
\text { berubah }\end{array}$ & Sesuai \\
\hline
\end{tabular}




\begin{tabular}{|c|c|c|c|c|}
\hline & $\begin{array}{l}\text { "winda@gmail.com" atau tidak } \\
\text { diisi }\end{array}$ & & & \\
\hline $\mathrm{C} 1$ & $\begin{array}{l}\text { Mengisi Nama } \quad \text { Kategori } \\
\text { dengan "Parabot" }\end{array}$ & $\begin{array}{l}\text { Sistem mampu } \\
\text { menyimpan data } \\
\text { kedalam database dan } \\
\text { mengalami perubahan } \\
\text { tampilan pada halaman } \\
\text { utama }\end{array}$ & $\begin{array}{l}\text { Sistem mampu } \\
\text { menyimpan data } \\
\text { kedalam database dan } \\
\text { mengalami } \\
\text { perubahan tampilan } \\
\text { pada halaman utama }\end{array}$ & Sesuai \\
\hline $\mathrm{C} 2$ & Tidak mengisi Nama Kategori & $\begin{array}{l}\text { Sistem menolak untuk } \\
\text { menyimpan data dan } \\
\text { data padad halaman } \\
\text { utama tidak berubah }\end{array}$ & $\begin{array}{l}\text { Sistem menolak } \\
\text { untuk menyimpan } \\
\text { data dan data pada } \\
\text { halaman utama tidak } \\
\text { berubah }\end{array}$ & Sesuai \\
\hline D1 & $\begin{array}{l}\text { Mengisi Nama Produk dengan } \\
\text { "ajinomoto", Harga diisi } \\
\text { dengan "1000", Harga Groris } \\
\text { diisi dengan "900", Harga } \\
\text { Pokok diisi dengan "900", } \\
\text { Satuan diisi dengan "Bungkus" } \\
\text { atau kosong, Stock diisi dengan } \\
\text { "497", Diskon diisi dengan "0", } \\
\text { Deskripsi diisi dengan } \\
\text { "Mantap" atau kosong }\end{array}$ & $\begin{array}{l}\text { Sistem mampu } \\
\text { menyimpan data } \\
\text { kedalam database dan } \\
\text { mengalami perubahan } \\
\text { tampilan pada halaman } \\
\text { utama }\end{array}$ & $\begin{array}{l}\text { Sistem mampu } \\
\text { menyimpan data } \\
\text { kedalam database dan } \\
\text { mengalami } \\
\text { perubahan tampilan } \\
\text { pada halaman utama }\end{array}$ & Sesuai \\
\hline D2 & $\begin{array}{l}\text { Mengisi Nama Produk dengan } \\
\text { "ajinomoto1", Harga diisi } \\
\text { dengan "1000abc", Harga } \\
\text { Groris diisi dengan "900ea", } \\
\text { Harga Pokok diisi dengan } \\
\text { "900zz", Satuan diisi dengan } \\
\text { "/Bungkus" atau kosong, Stock } \\
\text { diisi dengan "497z", Diskon } \\
\text { diisi dengan "0w", Deskripsi } \\
\text { diisi dengan "Mantap^_^" atau } \\
\text { kosong }\end{array}$ & $\begin{array}{l}\text { Sistem menolak untuk } \\
\text { menyimpan data dan } \\
\text { data padad halaman } \\
\text { utama tidak berubah }\end{array}$ & $\begin{array}{l}\text { Sistem menolak } \\
\text { untuk menyimpan } \\
\text { data dan data padad } \\
\text { halaman utama tidak } \\
\text { berubah }\end{array}$ & Sesuai \\
\hline E1 & $\begin{array}{l}\text { Mengisi Kode Barang dengan } \\
\text { kode yang terdaftar pada Daftar } \\
\text { Semua Produk lalu klik tombol } \\
\text { Beli }\end{array}$ & $\begin{array}{l}\text { Sistem mampu mencari } \\
\text { data dan menambahkan } \\
\text { barang sesuai kode } \\
\text { yang dicari ke tabel } \\
\text { Transaksi Penjualan }\end{array}$ & $\begin{array}{l}\text { Sistem mampu } \\
\text { mencari data dan } \\
\text { menambahkan } \\
\text { barang sesuai kode } \\
\text { yang dicari ke tabel } \\
\text { Transaksi Penjualan } \\
\end{array}$ & Sesuai \\
\hline $\mathrm{E} 2$ & $\begin{array}{l}\text { Tidak mengisi Kode Barang } \\
\text { lalu klik tombol Beli }\end{array}$ & $\begin{array}{lr}\text { Akan } & \text { muncul } \\
\text { peringatan } & \text { "Anda } \\
\text { belum } & \text { mengisikan } \\
\text { Kode Barang." }\end{array}$ & $\begin{array}{l}\text { Akan muncul } \\
\text { peringatan "Anda } \\
\text { belum mengisikan } \\
\text { Kode Barang." }\end{array}$ & Sesuai \\
\hline E3 & $\begin{array}{l}\text { Mengisi Kode Barang dengan } \\
\text { kode yang tidak terdaftar pada } \\
\text { Daftar Semua Produk lalu klik } \\
\text { tombol Beli }\end{array}$ & $\begin{array}{lr}\text { Akan muncul } \\
\text { peringatan "Maaf, Stok } \\
\text { Produk Habis atau } \\
\text { Produk } & \text { Tidak } \\
\text { Tersedia.." } & \end{array}$ & $\begin{array}{lr}\text { Akan } & \text { muncul } \\
\text { peringatan } & \text { "Maaf, } \\
\text { Stok Produk } & \text { Habis } \\
\text { atau Produk } & \text { Tidak } \\
\text { Tersedia.." } & \\
\end{array}$ & Sesuai \\
\hline
\end{tabular}

\section{Kesimpulan}

Dengan melaksanakan pengujian pada software yang dikembangkan dapat menjamin bahwa software yang dihasilkan telah bebas dari kesalahan. Dengan melakukan pengujian secara 
lengkap dan tepat dapat menghindarkan dari terjadinya kesalahan yang dapat merugikan.

\section{Saran}

Berdasarkan proses pengujian dan hasil pembahasan pengujian perangkat lunak Sistem kasir diharapkan melakukan pembuatan spesifikasi secara detail dan didokumentasikan secara tertulis dalam bentuk laporan serta pemberia keterangan setiap input yang ada. Laporan tersebut dapat menjadi bahan penelitian serta pengembangan sistem ke depannya.

\section{Referensi}

Asnawati, F. H. (2015). Rekayasa Perangkat lunak. Yogyakarta: Deepublish.

Astarina, I., \& Riasti, B. K. (2013). Pembuatan Sistem Penjualan Online Pada Toko PN Musik Sukaraharjo. Jurnal Speed, 10.

Cholifah, W. N., Yulianingsih, \& Sagita, S. M. (2018). Pengujian Black Box Testing Pada Aplikasi Action \& Strategy Berbasis Android Dengan Teknologi PhoneGap. Jurnal String.

Krismadi, A., Lestari, A. F., Pitriyah, A., Mardangga, I. W., Astuti, M., \& Saifudin, A. (2019). Pengujian Black Box berbasis Equivalence Partitions pada Aplikasi Seleksi Promosi Kenaikan Jabatan. Jurnal Teknologi Sistem Informasi dan Aplikasi, 2(4), 155-161.

Kurniawan, A., Maulana, A., Sukma, V. R., Keumala, W., \& Saifudin, A. (2020). Pengujian Black Boxpada Aplikasi Penjualan Berbasis Web Menggunakan MetodeEquivalents Partitions(Studi Kasus: PT Arap Store). Jurnal Teknologi Sistem Informasi dan Aplikasi, 51.

Liana, L. (2015). Pengujian Perangkat Lunak. Jurnal Rekayasa Perangkat Lunak, 2.

Myres, G. J., B. T., \& Sandler. (2012). The Art of Software Testing. Hoboken: John Wiley \& Sons, Inc.

Nurudin, M., Jayanti, W., Saputro, R. D., Saputra, M. P., \& Yulianti, Y. (2019). Pengujian Black Box pada Aplikasi Penjualan Berbasis Web Menggunakan Teknik Boundary Value Analysis. Jurnal Informatika Universitas Pamulang, 4(4), 143-148.

Purnama, B. E. (2013). Membangun Toko Online Dengan Wp Commerce. Yogyakarta: Graha Ilmu.

Shi, M. (2010). Software Functional Testing from the Perspective of Business Practice. Journal Computer and Information Science, 3.

Suprayitno, \& Wardati, I. U. (2012). Pembangunan Sistem Stok Barang Dan Penjualan Pada Toko Sero Elektronik. Indonesian Jurnal on Computer Sience Speed, 3.

Taufiq, R. (2018). Pengantar Sistem Informasi. Jakarta: Mitra Wacana Media. 